M. LIPIŃSKI*\# ${ }^{*}$, R.P. SOCHA**, A. KĘDRA**, K. GAWLIŃSKA*, G. KULESZA-MATLAK*,

Ł. MAJOR ${ }^{*}$, K. DRABCZYK*, K. ŁABA***, Z. STAROWICZ*, K. GWÓŹDŹ****, A. GÓRAL*, E. POPKO****

\title{
STUDYING OF PEROVSKITE NANOPARTICLES IN PMMA MATRIX USED AS LIGHT CONVERTER FOR SILICON SOLAR CELL
}

\begin{abstract}
The nanoparticles of $\mathrm{CH}_{3} \mathrm{NH}_{3} \mathrm{PbBr}_{3}$ hybrid perovskites were synthesized. These perovskite nanoparticles we embedded in polymethyl methacrylate (PMMA) in order to obtain the composite, which we used as light converter for silicon solar cells. It was shown that the composite emit the light with the intensity maximum at about $527 \mathrm{~nm}$ when exited by a short wavelength $(300 \div 450 \mathrm{~nm})$ of light.

The silicon solar cells were used to examine the effect of down-conversion (DC) process by perovskite nanoparticles embedded in PMMA. For experiments, two groups of monocrystalline silicon solar cells were used. The first one included the solar cells without surface texturization and antireflection coating. The second one included the commercial cells with surface texturization and antireflection coating. In every series of the cells one part of the cells were covered by composite $\left(\mathrm{CH}_{3} \mathrm{NH}_{3} \mathrm{PbBr}_{3}\right.$ in $\left.\mathrm{PMMA}\right)$ layer and second part of cells by pure PMMA for comparison. It was shown that External Quantum Efficiency EQE of the photovoltaic cells covered by composite $\left(\mathrm{CH}_{3} \mathrm{NH}_{3} \mathrm{PbBr}_{3}\right.$ in PMMA) layer was improved in both group of the cells but unfortunately the Internal Quantum Efficiency was reduced. This reduction was caused by high absorption of the short wavelength light and reabsorption of the luminescence light. Therefore, the $\mathrm{CH}_{3} \mathrm{NH}_{3} \mathrm{PbBr}_{3}$ perovskite nanoparticles embedded in PMMA matrix were unable to increase silicon solar cell efficiency in the tested systems.
\end{abstract}

Keywords: perovskite nanoparticles, light converters, solar cells, solar energy materials

\section{Introduction}

The materials of perovskite structure have been investigated for many decades due to their interesting properties including superconductivity, electron ferromagnetism, ferroelectricity, piezoelectricity and others. Recently, some groups of halide perovskites e.g. organo-metal-halide perovskites have attracted great attention in photovoltaic research. The general chemical formula of perovskite compounds is $\mathrm{AMX}_{3}$, where $\mathrm{A}$ and $\mathrm{M}$ are two cations of different sizes and $\mathrm{X}$ is an anion. In the organohalide perovskites, $\mathrm{A}$ is an organic cation like $\mathrm{CH}_{3} \mathrm{NH}_{3}{ }^{+}, \mathrm{X}$ is a halide anion $\left(\mathrm{F}^{-}, \mathrm{Cl}^{-}, \mathrm{Br}^{-}, \mathrm{I}^{-}\right)$and $\mathrm{M}$ is a metal cation like $\mathrm{Sn}^{4+}$ or $\mathrm{Pb}^{4+}$. The structure of these $\mathrm{AMX}_{3}$ compounds consists of the corner-sharing $\mathrm{MX}_{6}$ octahedra with A cation at cubo-octahedral sites.

Methylammonium lead triiodide $\left(\mathrm{CH}_{3} \mathrm{NH}_{3} \mathrm{PbI}_{3}\right)$ perovskite is the most common perovskite used in photovoltaics [1]. Miyasaka et al. [2] demonstrated the dye-sensitized solar cell containing $\mathrm{CH}_{3} \mathrm{NH}_{3} \mathrm{PbX}_{3}(\mathrm{X}=\mathrm{Br}, \mathrm{I}, \mathrm{Cl})$ as a dye. In 2009, the efficiency of perovskite containing solar cell was $3.8 \%$. This small efficiency was caused by solubility of the perovskite in the electrolyte. The replacement of the liquid electrolyte by spiro-MeOTAD i.e. the solid hole carrier material allowed to obtain higher efficiency. Actually, the certified power conversion efficiency (PCE) of methylammonium perovskite cells exceeded $15 \%$ [1-5]. New PCE record of $20.1 \%$ has been obtained recently for the cell of small active area fabricated with utilization of mentioned technology [6].

It was shown that three dimensional (3D) organo-halide perovskites were excellent light absorbers. They revealed good carrier transport properties and long carriers diffusion length [7-9]. Besides utilization of the 3D perovskites, there has been a big interest in low dimensional organo-halide perovskites. Due to reduced dimensionality, the bandgap and the exciton binding energy increased. The two dimensional structures of perovskites showed attractive optical properties like efficient photoluminescence, electroluminescence and non-linear optical effects due to strong quantum-confinement effect [10-14]. Important feature of these 2D perovskites is that they are more resistant to humidity than the $3 \mathrm{D}$ ones [15]. These structures consisted inorganic network of corner-sharing metal halide octahedra, which are separated by organic monolayers or bilayers. In this way, the

\footnotetext{
* INSTITUTE OF METALLURGY AND MATERIALS SCIENCE, POLISH ACADEMY OF SCIENCES, REYMONTA 25, 30-059 KRAKOW, POLAND

** JERZY HABER INSTITUTE OF CATALYSIS AND SURFACE CHEMISTRY POLISH ACADEMY OF SCIENCES, NIEZAPOMINAJEK 8, 30-239 KRAKOW, POLAND

*** CENTRE OF POLYMER AND CARBON MATERIALS POLISH ACADEMY OF SCIENCES, M. CURIE-SKŁODOWSKIEJ 34, 41-819 ZABRZE, POLAND

**** WROCLAW UNIVERSITY OF SCIENCE AND TECHNOLOGY, WYB. WYSPIAŃSKIEGO 27, 50-370 WROCŁAW 
self-organized quantum-well structures of metal halide-based layered perovskites were formed [14].

It has been shown recently $[16,17]$, that the nanoparticles of $\mathrm{CH}_{3} \mathrm{NH}_{3} \mathrm{PbBr}_{3}$ metal-organic hybrid perovskite can be relatively simply synthesized resulting in interesting optical properties. They emit light with a high quantum yield and they are stable in air. These quantum dots (0D) could be applied in photovoltaics. Especially, in third generation of the solar cells based on the quantum dots, which can reach very high efficiency beyond the Shockley-Queisser limit for the conventional solar cells [18].

The one of the most straightforward methods of quantum dots application in photovoltaics is their utilization for light conversion in down-conversion (DC) process, which is also known as quantum-cutting [19-25]. The down-converter transforms one high energy photon into two or more photons of lower energy but simultaneously higher than the bandgap. The down shifting (DS) is another effect that can be applied in PV [20]. Down shifting is similar to DC, but this light conversion lead to transformation of one photon to the only one photon. The Internal Quantum Efficiency (IQE) for high energy photons is higher than 1 for DC effect and lower than 1 for DS effect.

The DS can be used in order to improve the IQE in the range of short wavelengths. This kind of conversion can be particularly important in case of poorly passivated front side solar cells. However, the silicon solar cells produced recently have shown improved passivation by $\mathrm{SiN}_{\mathrm{x}}$ or $\mathrm{Al}_{2} \mathrm{O}_{3}$ layers. There is also a large absorption of ultraviolet and blue light in the module covering glass. The utilization of the down shifting effect before the light enters the glass could improve the efficiency of the module considerably [24].

All these kind converters are deposited on front surface of the Si solar cells or modules without any significant modification of the fabrication process. There are several materials, which can be used for the light converting purpose. The most promising ones are based on the semiconductor quantum dots embedded in the dielectric film [20].

In our work, the $\mathrm{CH}_{3} \mathrm{NH}_{3} \mathrm{PbBr}_{3}$ perovskite nanoparticles were chosen because it was shown that they have very high photo luminescence quantum yield and high stability $[16,17]$.

The $\mathrm{CH}_{3} \mathrm{NH}_{3} \mathrm{PbBr}_{3}$ perovskite nanoparticles were synthesized and their optical properties were investigated. The nanoparticles application as down-converting or down-shifting systems was examined. The light converting nanoparticles embedded into PMMA layer on the front side of the silicon solar cells were tested for this purpose.

\section{Experimental}

In our work, we prepared the colloidal solution of $\mathrm{CH}_{3} \mathrm{NH}_{3} \mathrm{PbBr}_{3}$ nanoparticles. All syntheses were performed in anhydrous environment inside the glove box. Before synthesis, all liquid chemicals were vacuum degassed. In first stage of the perovskite fabrication, $\mathrm{CH}_{3} \mathrm{NH}_{3} \mathrm{Br}$ and $\mathrm{CH}_{3}\left(\mathrm{CH}_{2}\right)_{7} \mathrm{NH}_{3} \mathrm{Br}$ precursors were synthesized. $\mathrm{CH}_{3} \mathrm{NH}_{3} \mathrm{Br}$ was synthesized by reacting stoichiometric amounts of methylamine (33\% in ethanol from Avantor) and hydrobromic acid (48\% in water from Sigma Aldrich), in $250 \mathrm{~mL}$ round-bottom flask for $3 \mathrm{~h}$ with stirring at $0^{\circ} \mathrm{C}$. To obtain $\mathrm{CH}_{3} \mathrm{NH}_{3} \mathrm{Br}$ crystallites, the solvent was removed using rotary evaporator for 2 hours at $50^{\circ} \mathrm{C}$. The product was washed in diethyl ether (3x) (99.8\% from Sigma Aldrich). After recrystallization from mixed solution of diethyl ether and ethanol (99.8\% from Acros Organics), the remaining solid was dried in a vacuum-oven for $24 \mathrm{~h}$ at $60^{\circ} \mathrm{C}$. The $\mathrm{CH}_{3}\left(\mathrm{CH}_{2}\right)_{7} \mathrm{NH}_{3} \mathrm{Br}$ was synthesized by reacting octylamine ( $99 \%$ from Alfa Aesar) with stoichiometric amount of hydrobromic acid.

$\mathrm{CH}_{3} \mathrm{NH}_{3} \mathrm{PbBr}_{3}$ perovskite nanoparticles were prepared according to the procedure described elsewhere [16]. Oleic acid (pure from VWR Chemicals) and 1-octadecene ( $90 \%$ from Sigma Aldrich) was stirred and heated at $80^{\circ} \mathrm{C}$. Then octylammonium bromide $(0.3 \mathrm{mmol})$ was added followed by addition of methylammonium bromide $(0.2 \mathrm{mmol}$ dissolved in $500 \mu \mathrm{l}$ of DMF (DMF ppa from CHEMPUR)) and lead(II) bromide ( $0.5 \mathrm{mmol}$ dissolved in $500 \mu$ l of DMF) (( $\mathrm{PbBr} 98 \%$ from Sigma Aldrich). Yellow product was precipitated by addition of acetone $(99.5 \%$, ppa, Sigma Aldrich) followed by centrifugation for $10 \mathrm{~min}$ at $7,000 \mathrm{rpm}$. The final product was dispersed in toluene $(99.5 \%$, ppa, Sigma Aldrich). The concentration of the starting perovskite suspension was $2.5 \mathrm{mmol} \mathrm{dm}^{-3}$.

For experiments, two types of silicon solar cells were used. The first group included, fabricated in our laboratory [26], solar cells of $5 \times 5 \mathrm{~cm}^{2}$ without surface texturization, antireflection coating and oxide passivation layers. The efficiency of these cells was small of about $10 \%$. The Internal Quantum Efficiency of these cells was low for the short wavelengths. Therefore, they were greatly suitable to verify how the perovskite layer improve IQE due to light conversion from short to longer wavelengths for which the cell shows higher IQE. The second series included the $2 \times 2 \mathrm{~cm}^{2}$ cells obtained by laser cutting of commercial, high efficiency (about 18\%) monocrystalline silicon solar cell with texturization and antireflection coating. These cells were used to verify the influence of composite layer on the IQE of high quality complete (with texturization and ARC) solar cells.

In order to examine the perovskite nanoparticles as light converter for Si solar cells, the perovskite nanoparticle suspension was added to the polymethyl methacrylate (PMMA) (from Alfa Aesar, molecular weight: 400 to 550) dissolved in toluene.

PMMA solution was prepared by mixing up $50 \mathrm{ml}$ of anhydrous toluene and 3.777 g PMMA granules (Alfa Aesar) then conditioned for $24 \mathrm{~h}$ in sonification bath. Subsequently, the mixture was stored for 17 days before use, which resulted in toluene evaporation $(14 \mathrm{ml})$. The $2 \mathrm{ml}$ of PMMA solution $(0.21 \mathrm{~g}$ of PMMA and $36 \mathrm{ml}$ of toluene) was mixed with $1 \mathrm{ml}$ of perovskite $\left(2.5 \mathrm{mmol} \mathrm{dm}^{-3}\right)$ suspension. The concentration of perovskite nanoparticles in PMMA was $925 \mathrm{mg}$ PMMA: $0.6 \mathrm{mg}$ $\mathrm{CH}_{3} \mathrm{NH}_{3} \mathrm{PbBr}_{3}$.

Increased concentration of the nanoparticles caused the very strong quenching of the emitted light. In other hand, the smaller value of perovskite concentration could not convert the light effectively. The perovskite concentration has not been optimized in 
our work yet, but allowed to test if these composite layer could be used as effective converter.

The resulting perovskite-PMMA-toluene suspension was deposited on front part of the silicon solar cells. The spin-coating method was used for this purpose. The solar cells of first type were coated by thick layer of composite and PMMA of about 20 micrometres. The speed of spinning was relatively low of about $1000 \mathrm{rpm}$. In the case of second group of the cells with ARC (antireflection coating), the speed of the spin-coater was about $3000 \mathrm{rpm}$. The speed was chosen larger because the thick layer of PMMA and composite layer deposited with lower speed strongly reduced the efficiency of solar cell. After deposition, the layers were dried in an oven at $150^{\circ} \mathrm{C}$ for about $15 \mathrm{~min}$.

\section{Results and discussion}

\subsection{Optical and structural characterization}

Figure 1 shows microstructure of the $\mathrm{CH}_{3} \mathrm{NH}_{3} \mathrm{PbBr}_{3}$ perovskite nanoparticles obtained by transmission electron microscope Tecnai G2 F20 $(200 \mathrm{kV})$ and structure analysis by XRD.

The perovskite nanoparticles are occluded in the organic matrix forming rectangular plate-like structures. The size of these structures is about $100-200 \mathrm{~nm}$ with agreement to the work by Schmidt et al. [16]. The image at larger magnification (Fig. 1c) confirms crystallinity of the perovskite particles. The electron diffraction pattern analysis (Fig. 1e) shows two rings, which

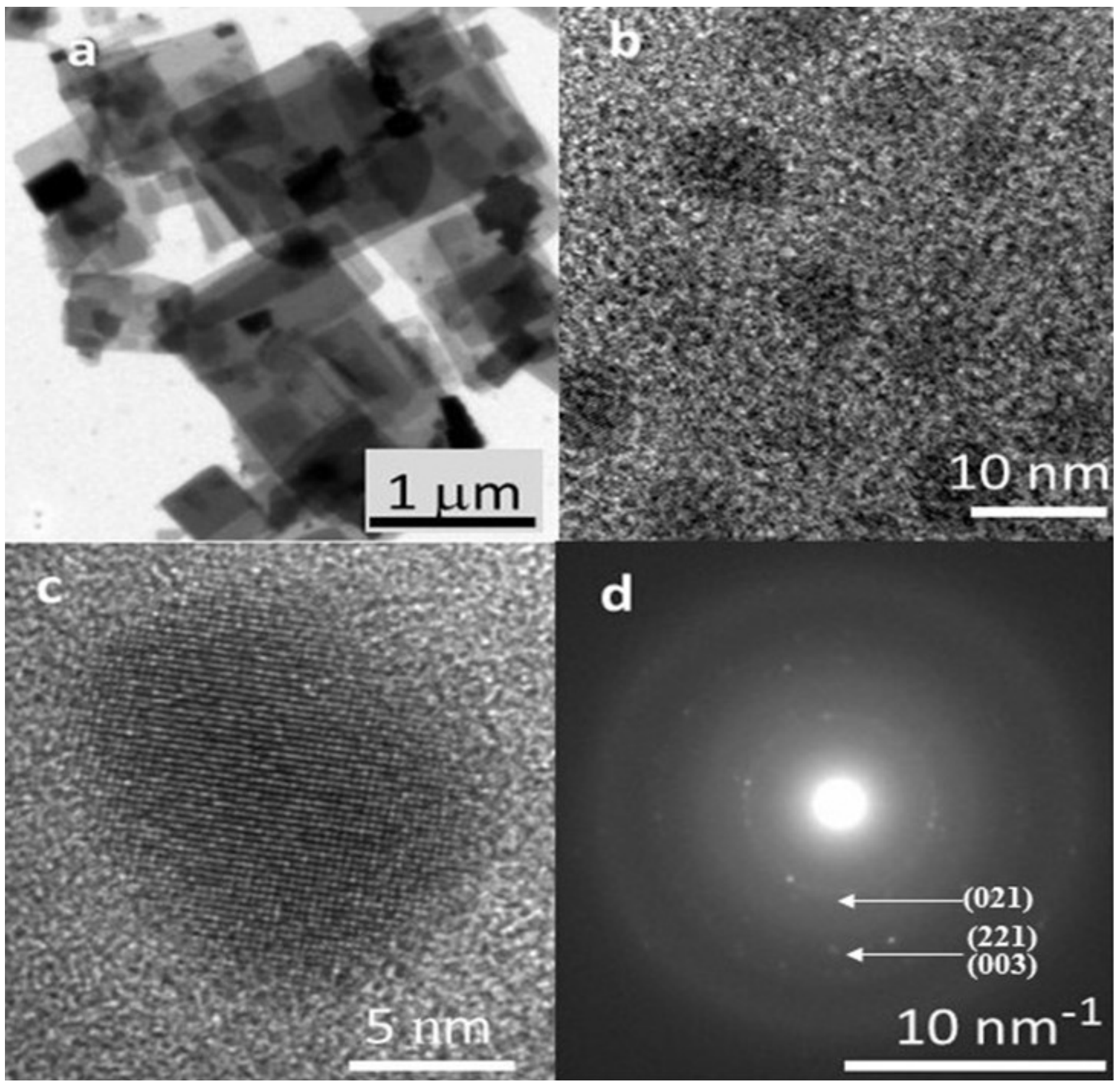

Fig. 1. The TEM image of the $\mathrm{CH}_{3} \mathrm{NH}_{3} \mathrm{PbBr}_{3}$ perovskite morphology (a), High Resolution TEM images (b,c) and electron diffraction pattern with two rings corresponded to (021), (221) and (003) faces of cubic phase according to ref. [27] (d) of the nanoparticles 
correspond to the (021), (221) and (003) faces of cubic phase according to ref. [27].

The particle size of $\mathrm{CH}_{3} \mathrm{NH}_{3} \mathrm{PbBr}_{3}$ perovskite is shown in Fig. 2. It indicates rather narrow particle distribution of $\pm 2.7 \mathrm{~nm}$ with maximum at $6 \mathrm{~nm}$. There is a tail for larger particle sizes observed in this histogram but number of this particles is insignificant.

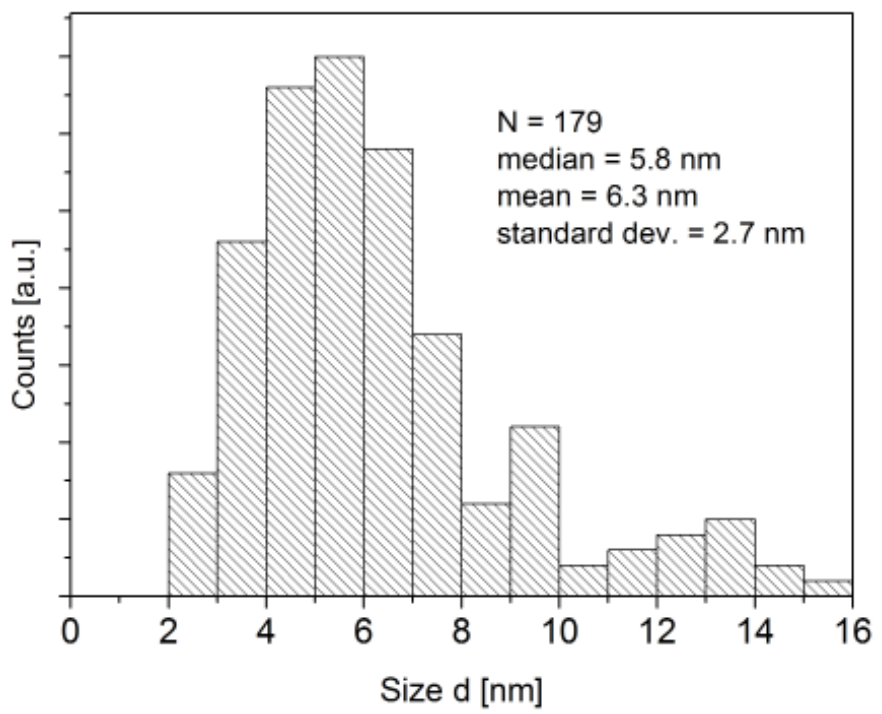

Fig. 2. The histogram of particle size distribution for perovskite nanoparticles presented in Figure 1

The X-ray diffraction (XRD) measurement was performed on powder diffractometer D5005 (Bruker/AXS). The XRD pattern presented on the Fig. 3 shows maxima, which correspond to $\mathrm{CH}_{3} \mathrm{NH}_{3} \mathrm{PbBr}_{3}$ cubic phase according to ref. [16].

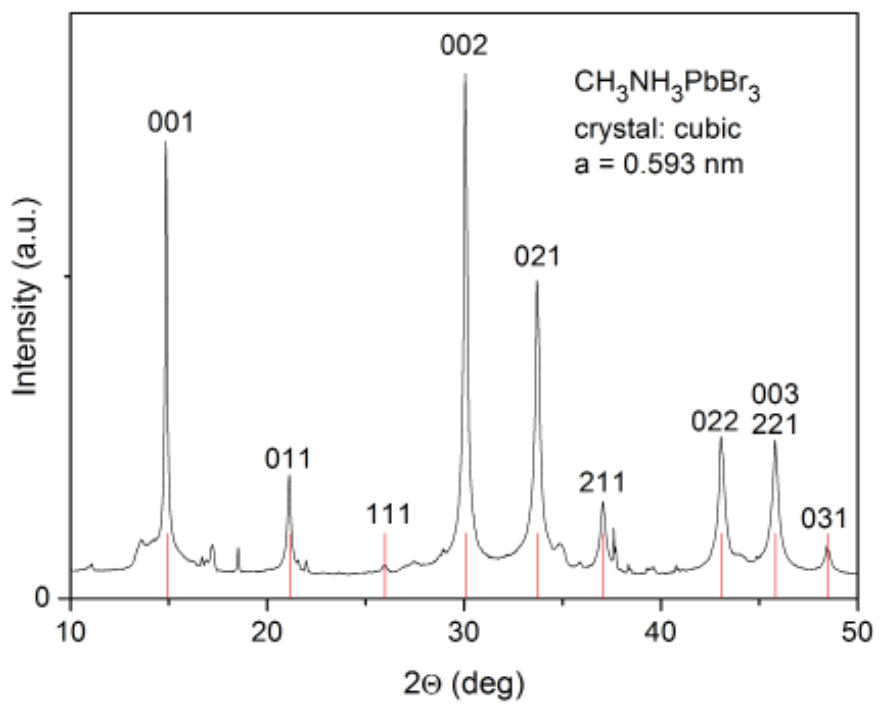

Fig. 3. The X-ray diffraction (XRD) pattern of investigated powder material. The marked maxima correspond to crystallographic planes of the $\mathrm{CH}_{3} \mathrm{NH}_{3} \mathrm{PbBr}_{3}$ cubic crystal phase according to ref. [16]

The photoluminescence of the perovskite particles embedded in PMMA was determined using HITACHI F-2500 Fluorescence Spectrophotometer. The fluorescence emission spectra were recorded for the different excitation wavelengths in the range of 300-450 $\mathrm{nm}$. The photoluminescence (PL) intensity depends on the excitation beam wavelength. Figure 4 shows photoluminescence spectra of the $\mathrm{CH}_{3} \mathrm{NH}_{3} \mathrm{PbBr}_{3}$ nanoparticles embedded into PMMA matrix. The spectra reveal high intensity emission maximum at $527 \mathrm{~nm}(2.35 \mathrm{eV})$ for excitation wavelength of $300 \mathrm{~nm}$. The maximum of PL is red shifted of about $2 \mathrm{~nm}$ for $450 \mathrm{~nm}$ excitation wavelength. The emission spectra are almost symmetrical with low value of FWHM (full width at half maximum) equal to $27 \mathrm{~nm}$ for $\lambda_{e x}=300 \mathrm{~nm}$.

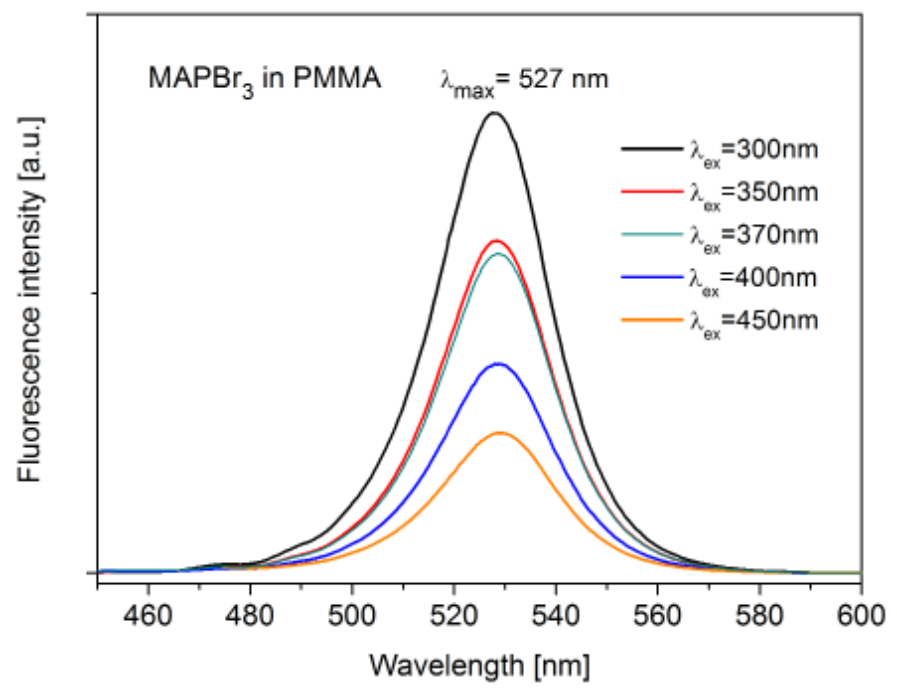

Fig. 4. The photoluminescence spectra of the $\mathrm{CH}_{3} \mathrm{NH}_{3} \mathrm{PbBr}_{3}$ nanoparticles in PMMA

The transmittance of the coating composed of $\mathrm{CH}_{3} \mathrm{NH}_{3} \mathrm{~Pb}$ $\mathrm{Br}_{3}$ nanoparticles embedded in PMMA layer deposited on the glass is shown in the Fig. 5. Additionally, Figure 5 shows reflectance of the perovskite-PMMA composite layer and transmittance of the glass. On a basis of these dependencies, the absorptions of the nanocomposite material and glass substrate were calculated ( $A=1-R-T)$ and also presented in Fig. 5.

The optical band gap energy $E_{g}$ was determined using Tauc's equation, given as:

$$
(\alpha h v)^{\gamma}=B\left(h v-E_{g}\right)
$$

where $\alpha$ is absorption coefficient, $h$ is Planck's constant, and $v$ is frequency of the radiation, $B$ is a constant and $\gamma=2$ for direct gap semiconductors and 0.5 for indirect gap ones.

The optical absorption coefficient can be calculated from $T$ and $R$ data. As a first approximation, a can be extracted from the formula [28]:

$$
T=(1-R) \exp (-\alpha d)
$$

where $d$ is absorbent layer thickness.

Figure 6 shows the Tauc plot $(\alpha h v)^{2}$ as function of the photon energy. The optical energy gap $E_{g}$ was determined by extrapolation of the linear part of the curve to $(\alpha h v)^{2}=0$.

The $\gamma$ value equal to 2 indicating that the $\mathrm{CH}_{3} \mathrm{NH}_{3} \mathrm{PbBr}_{3}$ nanoparticles have the direct gap band. The optical band gap 
edge was found at about $E_{g}=2.30 \mathrm{eV}$, which corresponds to the wavelength of $540 \mathrm{~nm}$.

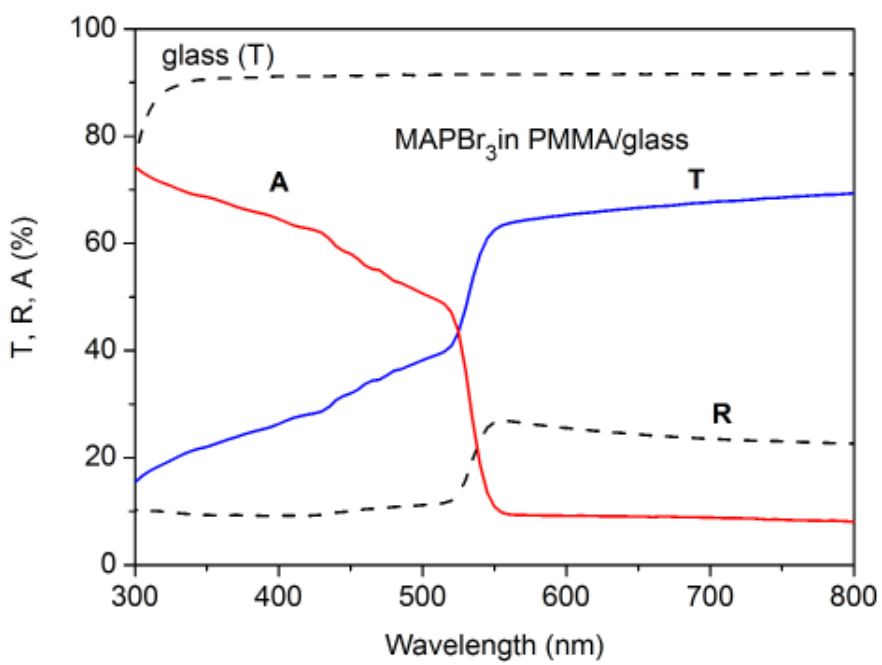

Fig. 5. Transmittance, reflectance and absorption spectra of the $\mathrm{CH}_{3} \mathrm{NH}_{3} \mathrm{PbBr}_{3}$ nanoparticles in PMMA deposited on the glass

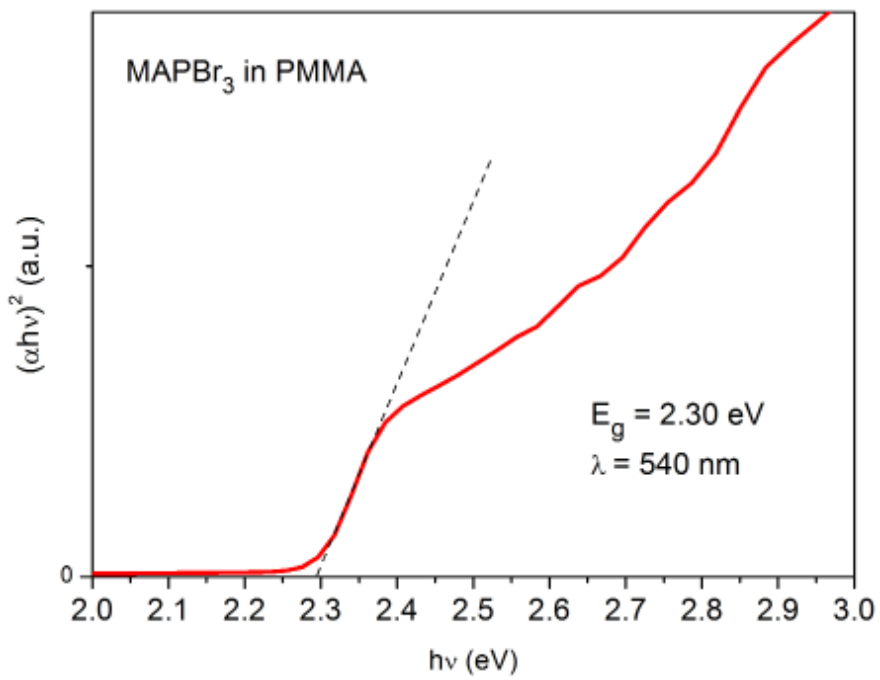

Fig. 6. The Tauc plot of the $\mathrm{CH}_{3} \mathrm{NH}_{3} \mathrm{PbBr}_{3}$ nanoparticles in PMMA deposited on the glass

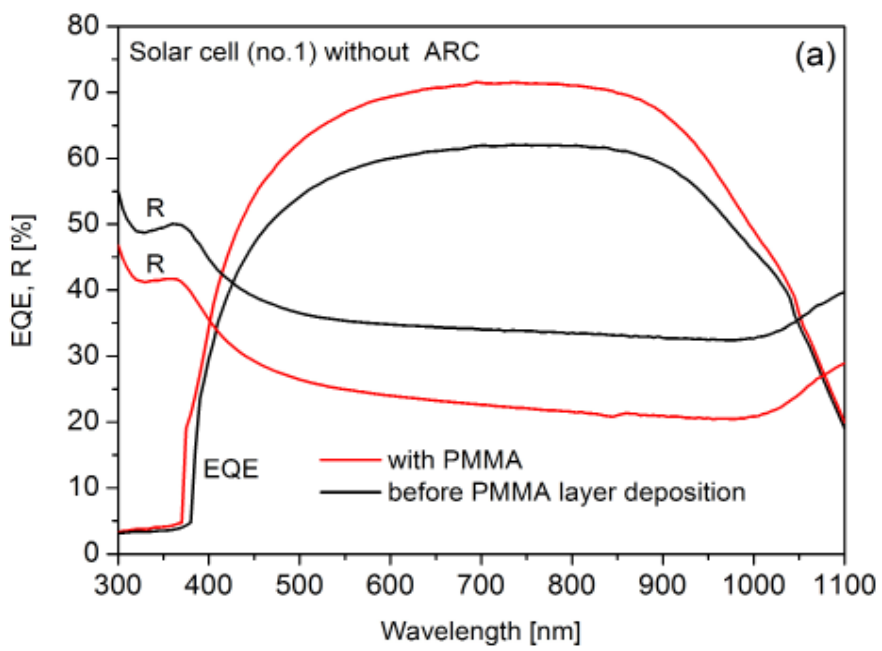

\subsection{Silicon solar cells with the composite $\left(\mathrm{CH}_{3} \mathrm{NH}_{3} \mathrm{PbBr}_{3}\right.$ in $\left.\mathrm{PMMA}\right)$ layer}

The influence of the perovskite composite layer $\mathrm{CH}_{3} \mathrm{NH}_{3} \mathrm{~Pb}$ $\mathrm{Br}_{3}$ nanoparticles embedded in PMMA on the external and internal quantum efficiency was investigated.

Two groups of cells were examined: the one without texturization and without ARC (antireflection coating) and the second with both texturization and ARC. Two kinds of coatings were investigated and compared: pure PMMA coating and perovskite $\mathrm{CH}_{3} \mathrm{NH}_{3} \mathrm{PbBr}_{3}$ nanoparticles embedded in PMMA coating deposited on the front of solar cells. The external quantum efficiency EQE and reflectance R of the cells were measured before and after deposition of the coatings by Bentham PVE 300 System (U.K.) and the internal quantum efficiency IQE was calculated.

The EQE, R and IQE of the solar cell with and without PMMA layer were presented in Fig. 7. The effect of the composite layer (perovskite $\mathrm{CH}_{3} \mathrm{NH}_{3} \mathrm{PbBr}_{3}$ nanoparticles in PMMA) on the R, EQE and IQE was showed in Fig. 8.

It can be observed in Fig. 8 that EQE increased after deposition of the PMMA and composite layers due to reduction of the reflectivity. However, the internal quantum efficiency was reduced after layer deposition. This reduction was caused by high absorption of the short wavelength $(\lambda<540 \mathrm{~nm})$ light and reabsorption of the luminescence light (with the peak for $527 \mathrm{~nm}$ ).

An analysis of the reflectance R, EQE and IQE dependencies indicated obviously that the composite layer of $\mathrm{MAPbBr}_{3}$ in PMMA worked predominantly as antireflection coating. The PMMA layer deposited on the silicon wafer shows an antireflective properties due to low value of refractive index of this layer $(n=1.5)$ in comparison to refractive index of silicon $(n=4.0$ for $\lambda=600 \mathrm{~nm}$ ). In turn, the down shifting process appeared to be insufficiently effective.

The Figures 9 presented the effect of PMMA and composite coatings on the EQE, R and IQE of the commercial silicon solar cells (with texturization and ARC coating). Two cells $2 \times 2 \mathrm{~cm}^{2}$ were obtained by laser cutting one solar cell.

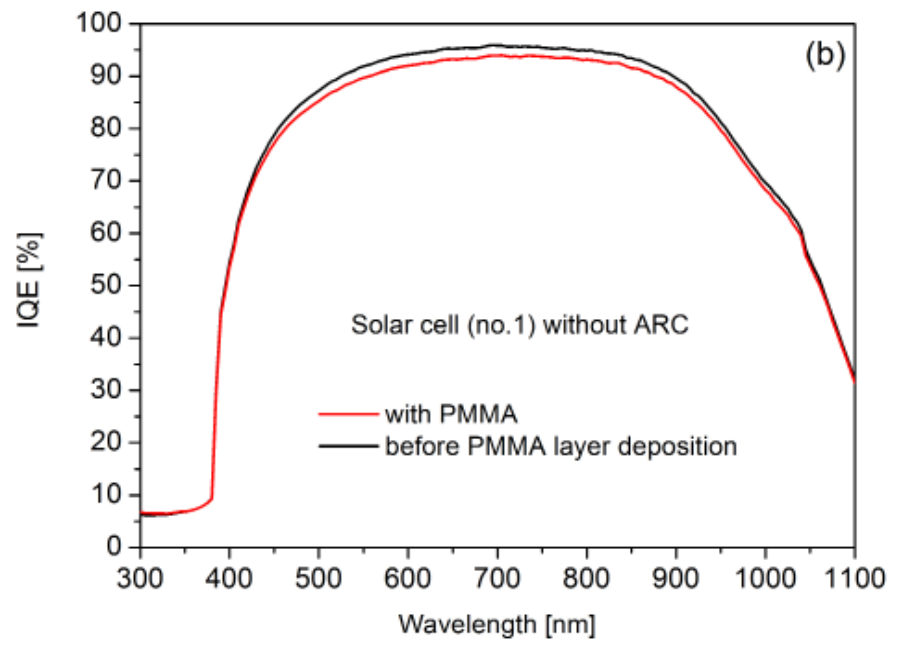

Fig. 7. The external EQE (a) and internal IQE (b) quantum efficiencies of the solar cell with and without the PMMA layer. The solar cell is without ARC. The small difference between IQE is caused by absorption of the PMMA layer 

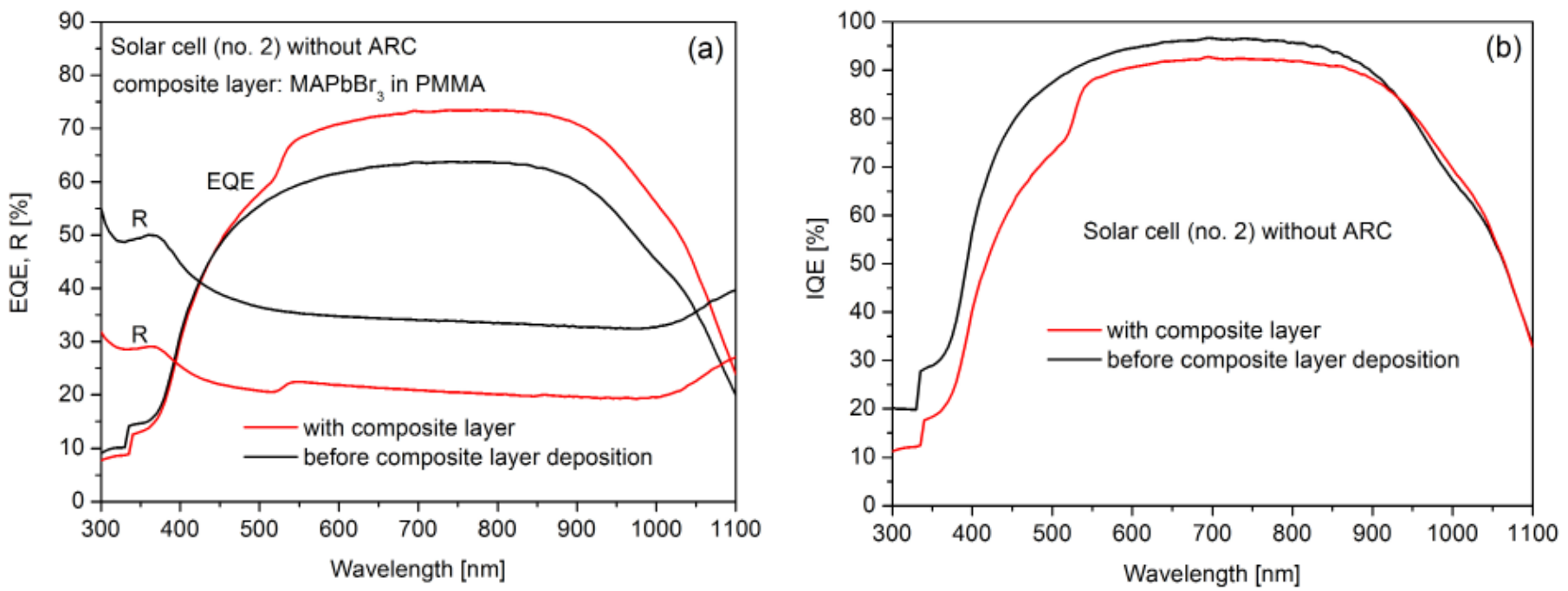

Fig. 8. The external EQE (a) and internal IQE (b) quantum efficiencies of the solar cell with and without the composite (MAPbBr ${ }_{3}$ in $\mathrm{PMMA}$ ) layer. The solar cell is without ARC. The difference between the IQE curves is caused by absorption of the composite layer
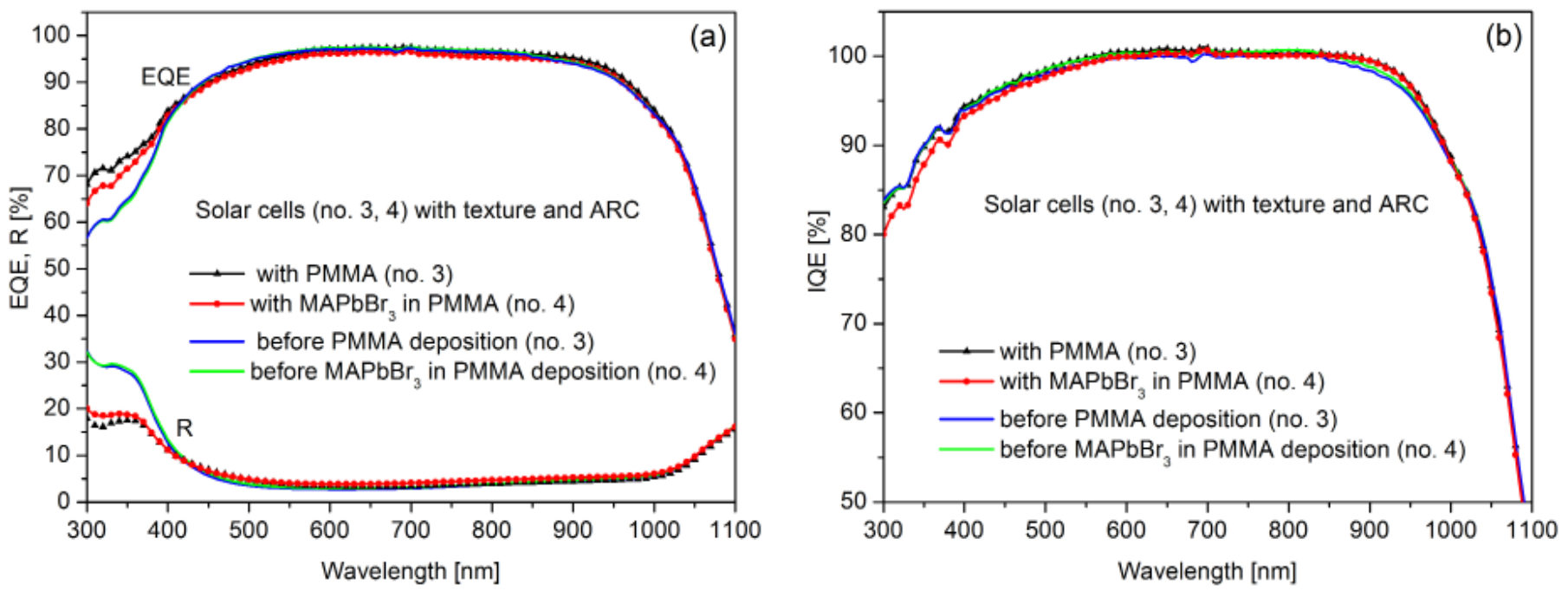

Fig. 9. The external EQE (a) and internal IQE (b) quantum efficiency of the (commercial) solar cell (with ARC) with and without the composite $\left(\mathrm{MAPbBr}_{3}\right.$ in $\left.\mathrm{PMMA}\right)$ layer. The composite layer reduce the IQE due to high absorption of this layer

The EQE of these cells were the same, therefore could be used as references to check the effect of PMMA and composite coatings on the IQE. The Figure 9a showed that EQE increased for the short wavelength in the 300-400 nm range due to reflectance reduction (by second coating PMMA or composite with refractive index of about 1.5). This increase is higher for pure PMMA coating, which is caused by light absorption of perovskite nanoparticles. The IQE of the cell with PMMA is the same as without PMMA coating, but IQE with composite layer is reduced for short wavelength $(300-400 \mathrm{~nm})$ in comparison to the system without this layer. The latter result is far from expectation for applied converter. Therefore, we can conclude, as with non-textured cell without ARC that the $\mathrm{MAPbBr}_{3}$ in PMMA composite cannot be applied in the present form as an element increasing silicon solar cells efficiency.

\section{Conclusions}

The perovskite $\mathrm{CH}_{3} \mathrm{NH}_{3} \mathrm{PbBr}_{3}$ nanoparticles were synthesized with the size in the range of $6 \pm 3 \mathrm{~nm}$. The composite of particles embedded in PMMA showed high luminescence at $527 \mathrm{~nm}$ and narrow emission band when excited by UV light of $300 \mathrm{~nm}$. The layer of this composite was deposited on the front of Si solar cell and resulted in increase of the EQE. However, the calculated IQE was reduced. The down shifting of the light was found to be insufficient to improve the solar cell IQE. This is caused by quenching of the emitted light due to re-absorbtion of the light by the nanoparticles perovskite. Therefore, we can conclude that $\mathrm{CH}_{3} \mathrm{NH}_{3} \mathrm{PbBr}_{3}$ perovskite nanoparticles embedded in PMMA matrix are unable to increase silicon solar cell efficiency in a form they were applied for. 


\section{Acknowledgements}

This work was supported by the Polish National Science Centre under the grant No. DEC-2012/05/B/ST8/00087.

\section{REFERENCES}

[1] P. Gao, M. Gratzel and M. K. Nazeeruddin, Energy Environ. Sci. 7, 2448 (2014).

[2] A. Kojima, K. Teshima, Y. Shirai, T. Miyasaka, J. Am. Chem. Soc. 131, 6050 (2009).

[3] J. Burschka, N. Pellet, S.-J. Moon, R. Humphry-Baker, P. Gao, M. K. Nazeeruddin, M. Gratzel, Nature 499, 316 (2013).

[4] M. Liu, M.B. Johnston, H.J. Snaith, Nature 501, 395 (2013).

[5] D. Liu, T.L. Kelly, Nat. Photonics 8, 133 (2014).

[6] M.A. Green, K. Emery, Y. Hishikawa, W. Warta and E.D. Dunlop, Prog. Photovolt: Res. Appl. 23, 805 (2015).

[7] S.D. Stranks, G.E. Eperon, G. Grancini, C. Menelaou, M.J.P. Alcocer, T. Leijtens, L.M. Herz, A. Petrozza, H.J. Snaith, Science 342, 341 (2013).

[8] G. Xing, N. Mathews, S. Sun, S.S. Lim, Y.M. Lam, M. Grätzel, S. Mhaisalkar, T.C. Sum, Science 342, 344 (2013).

[9] Q. Chen, H. Zhou, Z. Hong, S.Luo, H.-S. Duan, H.-H. Wang, Y. Liu, G. Li, and Y. Yang, J. Am. Chem. Soc. 136, 622 (2014).

[10] S. Zhang, G. Lanty, J.-S. Lauret, E. Deleporte, P. Audebert, L. Galmiche, Acta Materialia 57, 3301 (2009).

[11] M. Era, K. Maeda, T. Tsutsui, Thin Solid Films 331, 285 (1998).

[12] M. Era, S. Morimoto, T. Tsutsui, S. Saito, Appl. Phys. Lett. 65, $676(1994)$
[13] T. Hattori, T. Taira, M. Era, T. Tsutsui, S. Saito, Chem. Phys. Lett. 254, 103 (1996)

[14] Y. Li, G. Zheng, C. Lin, J. Lin, Solid State Sciences 9, 855 (2007).

[15] I.C. Smith, E.T. Hoke, D. Solis-Ibarra, M.D. McGehee, H.I. Karunadasa, Angew. Chem. Int. Ed. 53, 1(2014).

[16] L.C. Schmidt, A. Pertegas, S. Gonzalez-Carrero, O. Malinkiewicz, S. Agouram, G.M. Espallargas, H.J. Bolink, R.E. Galian, J. Perez-Prieto, J. Am. Chem. Soc. 136, 850 (2014).

[17] S. Gonzalez-Carrero, R.E. Galian J. Perez-Prieto, J. Mater. Chem. A 3, 9187 (2015).

[18] W. Shockley, H.J. Queeisser, J. Appl. Phys. 32, 510 (1961).

[19] T. Trupke, M. Green, P. Wurfel, J. Appl. Phys. 92, 1668 (2002).

[20] V. Svrcek, A. Slaoui, J. Muller, Thin Solid Films 451-452, 384 (2004).

[21] B.S. Richards, Sol. Energy Mater. Sol. Cells 90, 2329 (2006).

[22] V. Badescu, A. De Vos, A.M. Badescu, A. Szymanska, J Phys D: Appl Phys. 40, 341 (2007).

[23] X. Huang, S. Han, W. Huang, X. Liu, Chem. Soc. Rev. 42, 173 (2013).

[24] K.R. McIntosh, G. Lau, J.N. Cotsell, K. Hanton, D.L. Bätzner, F. Bettiol, B.S. Richards, Prog. Photovolt: Res. Appl. 17, 191 (2009).

[25] S.-M. Liu, W. Chen, Z.-G. Wang, J. Nanosci. Nanotechnol. 10, 1418 (2010)

[26] P. Panek, M. Lipiński, E. Bełtowska-Lehman, K. Drabczyk, R. Ciach, Opto-Electronics Review 11, 269 (2003).

[27] J. Lábár, Microsc. Microanal. 18, 406 (2012).

[28] F. Demichelis, G. Kaniadakis, A. Tagliaferro, E. Tresso, Appl. Opt. 26, 1737 (1987) 